\title{
The Effectiveness of Public Credit Guarantees in the Japanese Loan Market
}

\author{
Iichiro Uesugi, ${ }^{\dagger}$ Koji Sakai, ${ }^{\ddagger}$ and Guy M. Yamashiro ${ }^{\S}$
}

3 September 2008

\begin{abstract}
This paper examines the effectiveness of public credit guarantee programs in not only increasing the availability of loans to small and medium enterprises (SMEs), but in also improving the expost performance of borrowing firms. Using a unique panel data set, we identify the effects of a massive credit guarantee program implemented by the Japanese government from 1998-2001. While we do find that the availability of loans increased for program participants, when loans were provided by undercapitalized banks the increased liquidity persisted for only a few years. Further, the ex-post performance of program participants, with the exception of firms with sizable net worth, deteriorated relative to their non-participating counterparts.
\end{abstract}

JEL Classification Code: G28; G38; H81

Keywords: Credit crunch; Small and Medium Enterprises; Loan guarantees; Matching estimation

\footnotetext{
* An earlier version of this paper circulated as "Effectiveness of Credit Guarantees in the Japanese Loan Market," 2006 RIETI Discussion Paper Series 06-E-04. The authors would like to thank members of the Corporate Finance Study Group at RIETI for helpful advice and comments. Comments on an earlier version by Doug Diamond, Naoyuki Yoshino, Katsumi Matsuura, Shinji Mizukami, and Wako Watanabe are gratefully acknowledged. Permission to use the Survey of the Financial Environment by the Small and Medium Enterprise Agency of Japan is gratefully acknowledged.

† Corresponding author: Institute of Economic Research, Hitotsubashi University, iuesugi@ier.hit-u.ac.jp

† Institute of Economic Research, Hitotsubashi University and RIETI, sakai-koji@rieti.go.jp

$\S$ Department of Economics, California State University, Long Beach, gyamashi@csulb.edu
} 


\section{$1 \quad$ Introduction}

Governments often rely on credit guarantees, which ensure the repayment of defaulted loans, to facilitate the flow of funds to small businesses. In fact, according to Green (2003), credit guarantee programs are employed in almost 100 countries - about half of all countries in the world. Further, in contrast to other similar policy measures, such as direct lending, credit guarantee schemes appear to be gaining momentum worldwide.

The economic impact of credit guarantees has been examined in a variety of theoretical studies, including Mankiw (1986), Gale (1990, 1991), and Li (1998), to name a few. ${ }^{1}$ Broadly, the justification for government intervention in credit markets is that information problems result in inefficiencies in SME financing. On the other hand, government intervention may exacerbate information problems and worsen credit conditions.

Because of the importance, politically and in terms of financial commitment, of these programs, researchers from many countries, employing a variety of data sources, have empirically investigated the impact of these programs. Studies using aggregated data include Hancock and Wilcox (1998), Craig, Jackson, and Thomson (2005, 2007), and Hancock, Peek, and Wilcox (2008). While these types of studies have provided some insight into the impact of credit guarantee programs, their reliance on aggregate data is a drawback. Aggregation, by masking the true reactions of individual firms, makes it difficult to reach a definitive conclusion about the effectiveness of these programs.

Recently, an increasing number of studies using disaggregated data have attempted to quantitatively analyze the effectiveness of credit guarantees. On the bank-side, Wilcox and Yasuda (2008) find a significant increase in non-guaranteed lending after the introduction of government credit guarantees. Firm-level studies have been more numerous. Cowling (2007), for

${ }^{1}$ Other notable papers include Smith and Stutzer (1989), Innes (1991), Williamson (1994). 
example, finds that firms participating in the credit guarantee program in the U.K. have a reduced probability of being credit rationed. Riding and Haines (2001) and Riding, Madill, and Haines (2007) find positive job creation and increased loan availability amongst Canadian guarantee program users.

However, even these firm-level studies have data limitations. Some studies only have data on program participants, and some are unable to identify when firms enter into the program. Further, several studies rely only on cross-sectional data, meaning firm performance prior to and following the introduction of the program is not available. Finally, while most of the studies use firm data, not many also have information on each firm's financial institutions.

In this study, by utilizing a new and unique dataset, we are able to overcome these difficulties and correctly identify the effectiveness of the credit guarantee program in Japan. We employ a panel data set of 2,087 guarantee program users and 8,090 non-users, accompanied by information on each firm's financial institutions. We also focus on a specific credit guarantee program, which was unprecedented in size. For a limited period of time (1998-2001), the Japanese government guaranteed approximately 30 trillion yen worth of loans (or about 10 percent of total lending) to SMEs in a program officially known as the "Special Credit Guarantee Program for Financial Stability” (SCG program). Its intent was to alleviate the effects of a severe credit crunch among SMEs brought about by a contraction in the financial sector. What sets the SCG program apart from other credit guarantee schemes is that it was accessible by nearly all SMEs as long as they were not in default, were not tax delinquent, did not have significantly negative net worth, or were not "window-dressing" their balance sheets. In addition, the SCG program, like Japan's other existing loan guarantee programs, but unlike those provided in other countries, covered 100 percent of the default cost incurred by borrowers. Because of this setup, 
the SCG program provides a unique opportunity to determine if government credit programs improve the availability of loans and the performance of borrower firms.

The main contribution of the paper is twofold. First, we empirically ascertain the "effectiveness" of the credit guarantee scheme. In addition to considering loan availability, we also examine asset allocation and the ex-post performance of participating firms. To control for the differing characteristics of SCG users and non-users, we employ a matching estimation technique.

Second, we examine how the effectiveness of the scheme was affected by the incentives it created for Japanese financial institutions. The program was introduced at a critical period for the Japanese financial system. Due to the increasing amount of non-performing loans, the amount of capital held by Japanese banks was precipitously low, and, as a result, the credit market was severely distorted. As Diamond (2001) points out, financial institutions with low levels of capital recalled a number of loans in order to meet the capital ratio requirement set forth by the Bank for International Settlements (BIS). Under these circumstances, the SCG program had two possible, but contrasting outcomes. One possible outcome was that the program would help banks to finance projects previously unfunded due to the shortage of capital and thus increase the amount of loans to liquidity-constrained small businesses. The other possible outcome was that the program would allow undercapitalized banks to substitute non-guaranteed loans for guaranteed loans in order to reduce their exposure to risky loans.

We find that while the SCG program increased the availability of loans to participants, it decreased their profitability. Furthermore, program participants transacting with undercapitalized (major) banks only experienced an increase in available liquidity for a few years at most. Thus, although the program successfully alleviated the credit crunch, it also allowed undercapitalized 
major banks to substitute non-guaranteed loans with guaranteed loans. Further, the program reduced the incentive of lenders to require collateral, and adequately monitor these loans, which resulted in moral hazard, and thus exacerbated the ex-post performance of program participants. Only users with abundant net worth improved their ex-post performance.

The remainder of the paper is organized as follows. Section 2 describes the credit guarantee system in Japan, with particular attention paid to the SCG program. In Section 3, we review the previous literature and posit three empirical hypotheses on the effectiveness of the program. Section 4 contains a discussion of the data, while in Sections 5 and 6, we test the hypotheses posited in Section 3 using a matching estimation approach. Section 7 concludes.

\section{The Special Credit Guarantee Program}

In Section 2.1, we discuss the credit guarantee scheme, one of the most important government credit programs in Japan. Section 2.2 contains a detailed discussion of the Special Credit Guarantee Program.

\subsection{The Credit Guarantee System in Japan}

To facilitate the flow of funds to SMEs, the Japanese government has implemented a variety of programs, including the use of direct loans by government-backed financial institutions as well as loan guarantees. In terms of amount outstanding, government guarantees have been used more extensively than direct loans. Further, the use rate of guarantees is far higher than that of direct loans, with nearly 40 percent of all Japanese SMEs having received guarantees.

The credit guarantee system in Japan began in 1937 when the first credit guarantee corporation was established in Tokyo. After the Second World War, the system continued to develop. In 1948, the Japanese government established the Small and Medium Enterprise Agency 
(SMEA), which founded a number of prefectural guarantee corporations. The agency considered the guarantee system to be one of the major pillars of its SME financing policy. In 1951, the government began to partially insure loan guarantees, and the scheme has remained unchanged since. The system's current insurer is the credit insurance division of the Japan Finance Corporation for Small and Medium Enterprise (JASME). The division finances 70 to 80 percent of the repayments by the credit guarantee corporations. The amount of guarantees outstanding has grown in tandem with the Japanese economy. During the recessions of the 1970s and 1980s, the government frequently used the guarantee system as a convenient tool to stimulate activity in the SME sector.

Three parties are involved in credit guarantee transactions in Japan: a small business borrower, a financial institution, and the credit guarantee corporation, which is financially backed by the government. The first step in the process is the filing of an application with a credit guarantee corporation. Financial institutions, acting on behalf of the small business borrower, file the most of the applications, although some firms file on their own behalf. In the first case, the financial institution may implement a preliminary screening process before it actually delivers the guarantee application. The second step involves the examination of, and the decision on the application by the guarantee corporation. Finally, based on a letter of approval from the credit guarantee corporation, the financial institution extends a loan to the small business. The borrowing firm is then required to pay a guarantee premium, which is about 1 percent of the total amount extended. In cases where the firm is unable to repay its debt to the bank, the corporation covers the debt, whereupon it receives the loan claim. The corporation then collects the claim over the long-term by assisting with the firm's business restructuring. 
There are two additional points worth noting with regard to the guarantee system. The share of debt relief assumed by the guarantee corporation, as a percentage of the total loan claim is, in principle, 100 percent, which is unique to the Japanese guarantee system. The primary implication of this is that the financial institution bears no default risk, which significantly reduces the institution's incentive to examine and monitor the borrower. Second, collateral or guarantees are sometimes required for sizable loan contracts. For example, collateral can be required for loans of more than 80 million yen, and a third-party guarantor can be required for loans of more than 50 million yen.

\subsection{Introduction of the Special Credit Guarantee Program}

In the 1990s, as the Japanese economy entered a period of prolonged stagnation, public guarantees were frequently included in government economic stimulus packages. This culminated with the introduction of the Special Credit Guarantee Program for Financial Stability, which ran from October 1998 to March 2001. The purpose of the measure was to alleviate the severe credit crunch faced by the small business sector. Beneficiaries of the program were subject to little in the way of collateral or third-party guarantor requirements. The scale of the SCG program, in terms of funding, was unprecedented. It is presumably the largest single credit guarantee program ever implemented in any country. Funding was initially capped at 20 trillion yen, but, in 1999, the cap was increased to 30 trillion yen, which was more than 10 percent of all SME loans outstanding in Japan.

Another unique feature of the SCG program was its loose examination policy. An applicant could be rejected for a guaranteed loan only under certain conditions: significantly negative net worth, tax delinquency, default, or window dressing of balance sheets. Clearly, these were very lenient conditions and consequently most applications were approved. Hence, an 
astonishing number of small businesses benefited from the SCG program, with 1.7 million loan applications being approved, totaling 28.9 trillion yen in guaranteed loans. The amount of SME loans backed by guarantees is depicted in Figure 1, which clearly show that the introduction of the SCG program led to a significant increase in guaranteed loans.

The program, however, has come under increasing criticism. There are two major issues. First, financial institutions had incentives to substitute incumbent non-guaranteed loans by loans guaranteed by the SCG program. In principle, the credit guarantee corporations prohibited this asset substitution; yet, rumors are that many financial institutions have done this. The incentive to substitute was even higher when the incumbent non-guaranteed loans were failing or when the financial institution was short of capital and needed to reduce its holdings of risky assets.

Second, there is a concern about moral hazard. A series of media reports have exposed the blatant misuse of funds by some borrowing firms. Some borrowers made stock investments with loans guaranteed for daily company operations (Nikkei Financial Newspaper, February 16, 2000), others filed for bankruptcy less than one month after receiving loans (Nikkei Newspaper, January 11, 1999), and finally some, who were in no need of financing, simply obtained the loans because they could (Nikkei Newspaper, January 11, 1999).

Most of these abuses can be attributed to information problems that were worsened by the SCG program. Inherently, informational asymmetries exist between lenders and SMEs. Two features of the SCG program magnified these effects. First, due to the complete coverage of default costs by the credit guarantee corporation, private financial institutions had no incentive to properly screen or monitor their borrowers. Second, since the SCG program is less stringent with regard to collateral and personal guarantees than the general guarantee programs, borrowers tend to put in less managerial effort or take on riskier projects, which are typical symptoms of the 
moral hazard problem. A serious consequence of this behavior is firms defaulting on their loans, which has indeed been a major problem for Japan's credit guarantee system. As of the end of October 2004, credit guarantee corporations have paid out a total of 2.1 trillion yen. Of this amount, whatever cannot be collected from the delinquent firms, and is not covered by the guarantee and insurance premium, is financed by the government budget.

\section{The Economic Impact of Public Credit Guarantees}

Based on the existing theoretical and empirical literature, we put forward three hypotheses about the economic impact of public credit guarantee programs. Specifically, we discuss loan availability in Sections 3.1 and 3.2, and ex-post firm performance in Section 3.3.

\subsection{Alleviating the Credit Crunch}

Much of the theoretical literature on public credit guarantee schemes focuses on the mechanisms by which such schemes increase loan availability. Probably the most frequently used explanation, à la Stiglitz and Weiss (1981), concentrates on the role of asymmetric information between borrowers and lenders and in particular the role of hidden information, which results in the undersupply, or rationing, of lending in an unfettered equilibrium without government intervention (see, e.g., Mankiw, 1986; Gale, 1990, 1991; Innes, 1991). According to this explanation, the introduction of public credit guarantees results in an increase in the availability of loans by alleviating such hidden information problems.

An alternative model has been developed by Li (1998). This does not rely on hidden information but on hidden action and assumes positive verification costs in determining borrowers' ex-post performance, resulting in a wedge between the cost of external debt financing and internal financing. The consequence of the wedge is a suboptimal level of lending, which is 
alleviated by government intervention in the credit market. In particular, the model asserts that those borrowers endowed with insufficient wealth and faced with a severe liquidity constraint benefit the most from the guarantee scheme.

However, one can show that even in the absence of asymmetric information, the introduction of credit guarantees increases the supply of loans. Models along these lines are based around bank capital shortages, which induce a credit crunch. Diamond (2001) builds a model under certainty in which banks must satisfy the capital requirement. In order to meet the requirement, undercapitalized banks prefer to liquidate loans to cash-constrained borrowers rather than waiting until the next period when cash flow will be abundant. This model actually describes the situation in the Japanese loan market in the late 1990s and early 2000s quite well. ${ }^{2}$ Due to the credit crunch caused by the shortage of bank capital, many potentially profitable opportunities were not fully funded. Moreover, many undercapitalized banks terminated a large number of potentially profitable loans in order to satisfy the capital requirement. In this scenario, credit guarantees facilitate the flow of capital to fund these otherwise unfunded projects. Since banks need not bear the default costs of guaranteed borrowers, they are willing to finance these projects. Further, as Diamond (2001) implies, this additional lending effect is stronger for firms transacting with undercapitalized banks rather than those dealing with well-capitalized banks. To summarize:

Hypothesis 1 (Availability Hypothesis) Availability of loans increases for guarantee users. Furthermore, this positive effect is stronger for borrowers transacting with undercapitalized banks.

\footnotetext{
${ }^{2}$ Ogawa (2003), Yoshikawa and Motonishi (1999), and Woo (2003) empirically verify the existence of a credit crunch during the period. In a comprehensive survey on the Japanese economy and its financial markets, Hoshi and Kashyap (2004) state that the credit crunch story applies to Japan in the years 1997-1998.
} 


\subsection{Loan Portfolio Substitution by the Lender}

There is an alternative hypothesis about loan availability. In contrast to most of the theoretical literature, which predicts an increase in the availability of guaranteed loans, empirical researchers, along with practitioners and policy makers, are skeptical as to whether credit guarantees really increase the total amount of guaranteed and non-guaranteed loans supplied to guarantee users. Vogel and Adams (1997) propose a situation of loan portfolio substitution by the lender, that is, a situation in which the increase in guaranteed loans to a firm is offset by the decrease in non-guaranteed loans. This is especially likely to occur when lenders perceive that the loan guarantees are politically motivated and unprofitable. Although this assertion lacks a rigid theoretical foundation, many regard their argument as persuasive and plausible. ${ }^{3}$ In fact, this was one of the criticisms leveled against the SCG program in Japan.

Note that the level of bank capital again plays an important role. A bank with a lower capital ratio is motivated to reduce its holdings of risky assets. Under the Basel Accord, nonguaranteed loans have a risk weight of 100 percent, while guaranteed loans have a risk weight of 10 percent. Therefore, undercapitalized banks are more likely to substitute guaranteed loans with non-guaranteed loans. Hence, borrowers transacting with undercapitalized banks are likely to observe a decrease in non-guaranteed loans after receiving SCG loans and to see a smaller increase in total loans than users transacting with well-capitalized banks. To summarize:

\footnotetext{
${ }^{3}$ Wilcox and Yasuda (2008) propose another explanation for the loan portfolio substitution. They assume that the relationship between guaranteed and non-guaranteed loans is a function of the debt collection process. Each lender then aims to maintain the same level of loss given default (LGD). The model emphasizes the role of the borrower's initial endowment in determining relative holdings of these two different types of loans. When the borrower has a positive endowment, guaranteed loans are likely to increase the lender's LGD, since the lender must yield a portion of the initial endowment to the guarantee corporation in the case of default. In order to maintain a particular level of LGD, the lender will decrease non-guaranteed loans, in which case we observe a negative relationship between guaranteed and non-guaranteed loans.
} 
Hypothesis 2 (Substitution Hypothesis) Increased availability of guaranteed loans to firms is offset by a decrease of non-guaranteed loans, resulting in an insignificant increase in loan availability. Credit guarantee users transacting with undercapitalized banks observe a smaller increase in the availability of loans relative to those transacting with highly capitalized banks.

\subsection{Effects on Ex-post Performance}

The models discussed in Section 3.1 also have implications for the ex-post performance of borrowers. Under asymmetric information, many profitable investment opportunities are unfunded in the unfettered equilibrium. ${ }^{4}$ Diamond (2001) suggests that under certainty, undercapitalized banks miss a number of profitable lending opportunities. The implication is that the financial constraint is alleviated, and the profitable projects are implemented upon the introduction of credit guarantees. Hence, the ex-post performance of program participants should improve. We call this positive effect the "investment effect."

Working in the opposite direction, however, is a "moral hazard effect," which worsens the ex-post performance of borrowers. As previously indicated, the 100 percent coverage of default costs by the credit guarantee corporation reduces the incentives for financial institutions to adequately monitor guarantee users. As described in the credit market model presented in Freixas and Rochet (1997), the moral hazard problem is induced by infrequent monitoring. In addition, the easing of requirements on collateral and third-party guarantees in the SCG program further exacerbated information problems. Reduced requirements for collateral are costly to lenders. For

\footnotetext{
${ }^{4}$ Note, however, that this assertion is dependent on the risk-return relationship of investment projects. Mankiw (1986) and Gale (1990, 1991) assume second-order stochastic dominance, in which projects with higher expected returns are not implemented in an unfettered pooling equilibrium. In contrast, deMeza and Webb (1987) assume first-order stochastic dominance, and conclude that any unfunded project has negative net present value and government intervention is not needed.
} 
example, Boot, Thakor, and Udell (1991) find that managers of firms that pledge no collateral are less likely to exert managerial effort, while Stulz and Johnson (1985) show that firms are more likely to sell assets to make risky investments when they do not pledge their assets as collateral. To summarize:

\section{Hypotheses 3a and 3b (Investment effect versus Moral Hazard effect) Ex-post}

performance of firms using credit guarantees improve since they are able to implement profitable projects with positive net present values. Alternatively, guarantee users succumb to moral hazard and, therefore, have lower profitability and/or a higher probability of falling into financial distress.

\section{$4 \quad$ Data and Empirical Methodology}

In this section, we discuss the data and empirical methods used, focusing, in particular, on the matching estimation procedure (Section 4.3).

\subsection{Data Sources}

We construct our firm-level panel data set from two sources. Our sample is based on the Surveys of the Financial Environment (SFE), implemented by the Small and Medium Enterprise Agency of Japan in the years 2001-2004. We supplement this data with information from the Financial Information Database (FID), which is collated by Tokyo Shoko Research, Incorporated, and covers the years 1998-2005. Our final data set consists of 55,588 firm-level observations covering the period $1998-2005 .{ }^{5}$

Our data has three primary advantages over what has been used in previous studies. First, by focusing on the SCG program, which was temporary, we can precisely identify when firms began participating in the program. Many of the existing empirical studies only have

\footnotetext{
${ }^{5}$ For a detailed discussion of the construction of the panel, see the Appendix.
} 
information on whether a firm is a participant or not, without specifying when they started participating. Second, since the panel covers six years, we can identify both the short- and medium-term effects of the program. Although cross-sectional data may identify whether the introduction of a credit guarantee program immediately increases loan availability, there are also additional longer-term effects that are only identifiable with panel data. These include firm profitability and default probability. Finally, our data includes both borrower and bank characteristics, while most previous studies include only one of these two. The data set thus is not only able to capture the difficult financial condition of Japanese banks, but also allows us to evaluate how a bank's financial situation influences the effectiveness of credit guarantee programs among user firms.

\subsection{Variables}

A list of the variables used in our empirical analysis and their definitions is provided in Table 1. We consider four categories of variables: use of the SCG program, borrower characteristics, characteristics of borrowers' financial institutions, and variables describing the relationship between borrowers and their financial institutions. We further divide the second category of variables on borrower characteristics into four subcategories: loan availability, asset allocation, performance, and general. Table 2 presents summary statistics of these variables for the sample of firms for the year prior to the introduction of the SCG program. The sample is further subdivided into firms that eventually used the SCG program and those that did not, with the summary statistics for both groups also shown in Table 2.

\subsection{Empirical Approach}

Unfortunately, a simple comparison of the ex-post performance of SCG users and nonusers is not appropriate. Users of the program are generally not a random sample of the 
population. Thus, the same firm characteristics, which determine participation in the program, also influence a firm's ex-post performance. For example, riskier firms that cannot borrow without securities tend to use credit guarantees. In contrast, less risky firms that have easy access to credit markets prefer not to use credit guarantees since the guarantees come with additional costs. If the riskier group has, relative to the safer group, fewer profitable investment opportunities, then a simple comparison between users and non-users results in an underestimation of the program's impact. We therefore have to control for any possible selection bias to reduce any potential estimation biases. To do so, we employ a matching estimation approach. The procedure is as follows.

(i) We first use a probit model to estimate the probability of borrowers' participating in the SCG program in year $t$, conditional on covariates observed in the previous year, $t-1$. Borrowers joining the program $\left(S C G_{t}=1\right)$ are the treatment observations. A propensity score is then attached to each observation. The propensity score $e(\bullet)$ is defined as

$$
e\left(X_{t-1}\right) \equiv \operatorname{Pr}\left(S C G_{t}=1 \mid X_{t-1}\right)
$$

where $X_{t-1}$ is a vector of firm and bank characteristics in year $t-1$.

(ii) We then identify $k$ matched (control) observations from the non-user sample for each treatment observation. The control observations are the closest non-user observations to the treatment observation in terms of propensity score. Note that the control observations are chosen from the same calendar year as the treatment observation. The number of control observations, $k$, is arbitrarily determined. ${ }^{6}$

(iii) Finally, we compare changes in the performance variables of the treatment and the control group for years $t-1$ to $t+i$, where $i=0,1,2,3,4$.

\footnotetext{
${ }^{6}$ In our estimations we use $k=5$.
} 
A benefit of the matching estimation approach is that we are able match the treatment and control observations using the scalar propensity score. The propensity score, which is the conditional probability of being treated given the observed characteristics, is a very useful variable in dealing with a highly dimensional vector of covariates. Rosenbaum and Rubin (1983) show that treatment observations (in our case those who join the SCG program) and control observations (those who do not use it) with the same propensity score value have the same distribution over the full vector of covariates. In this case, in order to obtain the same probability distribution of the covariates for the treatment and control observations it is sufficient to match firms only in terms of propensity scores.

To ensure that we have an unbiased estimator of the treatment effect, the balancing hypothesis must be satisfied,

$S C G_{t} \perp X_{t-1} \mid e\left(X_{t-1}\right)$

In other words, for a given propensity score, treatment observations are randomly chosen, and therefore, the treatment and non-treatment samples are on average identical. Thus, after implementing the first step of the matching estimation, we verify that (2) holds. The testing procedure entails: (i) splitting the sample such that the average propensity score of the treated and

non-treated groups are identical, and (ii) within all intervals of the propensity score, the means of every element of $X_{t-1}$ do not differ significantly between treated and non-treated units.

\section{$5 \quad$ Examining the Effect of the SCG Program}

In Section 5.1, we use a probit model to estimate a propensity score for each observation. We then estimate the treatment effect of the SCG program in Section 5.2, while Section 5.3 includes several robustness checks. 


\subsection{Propensity Score Estimation}

The testing procedure begins with the propensity score estimation (Equation 1). As discussed previously, the propensity score is the conditional probability of participating in the SCG program in year $t$ given the values of the observed borrower and bank characteristics in the previous year. In the estimation, the dependent variable is simply a binary variable indicating firm participation in the SCG program in year $t\left(S C G_{t}\right) . X_{t-1}$ is a vector of explanatory variables, and consists of six groups of variables. The first group (Availability) consists of information on the availability of credit to a firm, the second (Allocation) describes firms' allocation of assets, the third (Performance) consists of information on firm performance, the fourth (General) includes information on the firm's industry, size and age, the fifth (Bank) contains bank characteristics, and finally the sixth (Relationship) includes information on the relationship between a firm and its lender. Hence, we estimate the following probit model:

$$
\operatorname{Pr}\left(\text { SCG }_{t}=1 \mid X_{t-1}\right)=\Phi\left(\begin{array}{l}
\beta_{0}+\beta_{1} \text { Availability }_{t-1}+\beta_{2} \text { Allocation }_{t-1}+\beta_{3} \text { Performance }_{t-1} \\
+\beta_{4} \text { General }_{t-1}+\beta_{5} \text { Bank }_{t-1}+\beta_{6} \text { Relationship }_{t-1}
\end{array}\right)
$$

The estimation results are presented in Table $3 .^{7}$ LOANRATIO, MATURITY, and RATE are all positive and significant. This implies that loan-dependent firms, especially those dependent on long-term loans, and firms with large interest payments are more likely to use the program. In contrast, $C A S H, W C A P$, and FCAP are all significantly negative, indicating that firms with abundant liquid assets as well as fixed tangible assets are less inclined to use the program. ICOVER is negative and significant as well. This is not surprising, since profitable firms that easily cover their interest payments should be less likely to use the program.

\footnotetext{
${ }^{7}$ Note that for the given specification we verify the balancing hypothesis (Equation 2). In each of the six stratified intervals of the propensity score, we find that the variables employed in the propensity score estimation do not significantly differ across the treatment and non-treatment groups.
} 
While the weakly significant positive coefficient on $R O A$ is counterintuitive, it does make sense once we take into account that the variable is highly correlated with interest coverage. If interest coverage falls below the threshold value of one, the probability that the firm will join the program increases. In contrast, if the firm becomes insolvent (a negative capital ratio), the probability of joining decreases. Taken together, this implies that financially distressed firms are more likely to use the guarantee program, given that they are solvent.

The signs on $L n L O A N$ (significantly negative) and LnAGE (significantly positive), reveal that older and smaller borrower firms are more likely to use the SCG program. LnRELYEAR (negative) and NUMBANK (positive) indicate that firms with closer relationships to a financial institution, and those with a smaller number of alternative financial institutions to borrow from, are less likely to use the SCG program. Finally, we find that banks with lower levels of capital (BANKCAP) are more likely to participate in the program. When we consider regional financial institutions, however, BANKCAP is insignificant, since the coefficients for BANKCAP and $B A N K C A P^{*} R E G I O N A L$ offset each other. This is consistent with government policy in our sample period: undercapitalized major banks, most of which needed to abide by the 8 percent capital requirement, faced severe pressure to increase their capital ratios at this time, and for these banks, loans fully covered by public credit guarantees were preferable to loans not guaranteed by the SCG scheme. In contrast, since regional financial institutions were under little pressure to increase their capital ratios, the incentive structure, in terms of guaranteed lending, for undercapitalized regional institutions was the same as for well-capitalized regional institutions.

\subsection{Treatment Effect Estimation}

To estimate the treatment effect of the SCG program, we match each treated observation in year $t$ (2,087 observations) with the five nearest neighboring non-user observations in the same 
calendar year, where distance is measured in terms of propensity scores. We then measure the impact of the program on borrowers' loan availability (LOANRATIO, LONGRATIO, SHORTRATIO, and RATE), asset allocation (CASH, WCAP, and FCAP), and performance (DEFAULT, CAP_NG, and ICOVER_SM). For each subsample (treatment and control) we take the differences for each variable between periods $t+i$ and $t-1$, where $i=0,1,2,3,4$. For example, in the case of loan availability, we calculate $\triangle L O A N R A T I O_{t+i}^{j} \equiv L O A N R A T I O_{t+i}^{j}-L_{\text {LANRATIO }}^{j}$, where $j=\{$ Treatment, Control $\} .^{8}$ We then compare the differences across the treatment and the control groups by taking yet another difference. For example, $\Delta^{2} L O A N R A T I O_{t+i} \equiv \Delta L O A N R A T I O_{t+i}^{\text {Treatment }}-\Delta L O A N R A T I O_{t+i}^{\text {Control }}$. This is the treatment effect.

The results are presented in Table 4 . The treatment effect calculated across the entire sample is considered the base case. In the first two columns of the table, we present the means of the differences of each variable for the treatment and the control groups, respectively. The last column displays the identified treatment effect, or the difference in differences. For each variable, there are five estimates of the treatment effect corresponding with each of the five different time horizons.

Consistent with the availability hypothesis (Hypothesis 1), there is strong evidence of a positive treatment effect for loan availability. SCG users, relative to non-users, experience a significant increase in the availability of loans. This is also true for long-term loans. Between $t-$ 1 and $t$, the LOANRATIO treatment effect $\left(\Delta^{2} L_{\text {LOANRATIO }}\right)$ is 2.1 percentage points, while the LONGRATIO treatment effect $\left(\Delta^{2} L O N G R A T I O_{t}\right)$ is 2.2 percentage points. Over longer time

\footnotetext{
${ }^{8}$ Since we do not have data on defaults prior to year $t, \Delta p_{t+1}^{j}(D E F A U L T=1)$ is actually $p_{t+1}^{j}(D E F A U L T=1)$.
} 
horizons, the results are not qualitatively different. $\Delta^{2} L O A N R A T I O_{t+4}$ is 3.7 percentage points and $\Delta^{2} L O N G R A T I O_{t+4}$ is 1.4 percentage points. The treatment effect for short-term loans is generally insignificant, with one exception. The availability of long-term funds is more important than the availability of short-term funds for the firms' survival. Note, however, that the SCG program does not have a positive effect on all of the loan procurement conditions. The treatment effect for the interest payment rate indicates that the price of loans actually increases more among SCG users. $\Delta^{2} R A T E_{t}$ is 0.1 percentage points, with the difference increasing with the time horizon.

We further find that increased leverage coincides with a moderate increase in the tangible fixed assets ratio, that is, $\triangle^{2} F C A P_{t}$ is 0.3 percentage points and weakly statistically significant. In contrast, $\Delta^{2} C A S H_{t+i}$ and $\Delta^{2} W C A P_{t+i}$ indicate no significant treatment effects. Thus, the SCG program had only a minimal effect on firm asset allocation.

Finally, we turn to firm performance. SCG users have subsequent lower profitability, and higher probabilities of falling into financial distress. The coefficients on $\Delta^{2} R O A_{t+i}$ are significantly negative for the first three years, i.e., $t, t+1$, and $t+2$, with $-0.4,-0.4$ and -0.5 percentage points, respectively. In addition, $\Delta^{2} p_{t+i}\left(I C O V E R_{-} S M=1\right)$ is always significantly positive, ranging between 3 and 7 percentage points. Further, resulting from the decline in profitability, there are more observed cases of insolvency and defaults amongst SCG participants, as $\Delta^{2} p_{t+i}\left(C A P_{-} N G=1\right)$ is significant and positive after $t+3$ and $\Delta^{2} p_{t+i}(D E F A U L T=1)$ is significant and positive in both $t+2$ and $t+3$. These results, taken together, suggest that firm performance among SCG users deteriorated more than among non-users. Hence, in terms of our 
hypotheses posited above, we find evidence for a moral hazard effect (Hypothesis 3b) rather than for an investment effect (Hypothesis 3a).

\subsection{Robustness Check for Different Matching Algorithms}

Because there are a variety of matching algorithms, before we can be confident about our results, we need to examine the robustness of the treatment effect estimation across these different methodologies. For instance, there is a trade-off between matching quality and variance in the choice of how many non-user observations to match to a single treatment observation. In the base case, we set the number of matched non-treatment observations $(k)$ to 5 . While a one-toone match $(k=1)$ usually entails an efficiency loss, a larger $k$, although improving the quality of the match, increases bias. Moreover, there exist other matching algorithms, such as radius matching and kernel matching. We therefore check our base case treatment estimation by implementing the following matching algorithms: 10 nearest propensity score matching, kernel matching, and radius matching.

The results are displayed in Table 5. It is clear that the treatment effects do not qualitatively differ across the alternative matching algorithms. Positive and significant effects for loan availability, slightly positive and significant effects for asset allocation, and negative and significant effects for firm performance hold across the different methodologies.

\section{$6 \quad$ Treatment Effects across Different Subsamples}

The base case estimation in the previous section provides evidence in support of the availability hypothesis (Hypothesis 1) and the moral hazard hypothesis (Hypothesis 3b), rather than the substitution hypothesis (Hypothesis 2) and the investment hypothesis (Hypothesis 3a). Several important issues remain unresolved, however. In Section 6.1, we examine how financial 
institutions' financial conditions affect the different treatment effects. In Sections 6.2 and 6.3, we take a closer look at exactly how the moral hazard effect overrides the investment effect amongst SCG users.

\subsection{Different Bank Capital Levels}

Although the base case estimation supports the loan availability hypothesis, we cannot, as of yet, definitively say whether the bank capital shortage positively or negatively affects the increased loan availability. As Hypotheses (1) and (2) make clear, the financial institution's capital position matters. If Hypothesis (1) is correct, the increase in the availability of loans will be stronger for those firms dealing with undercapitalized banks. On the other hand, Hypothesis (2) predicts no significant increase in the supply of loans for firms transacting with undercapitalized banks.

We proceed by subdividing the treatment observations into two groups: those transacting with major banks and those transacting with regional financial institutions. We choose bank type as the dividing criterion for two main reasons. First, all the major banks needed to abide by the stringent BIS capital requirement, which was set at 8 percent, since they had international operations. In contrast, most of the regional financial institutions did not have international operations and were, thus, exempt from the BIS capital requirement. They only needed to abide by the (looser) capital requirement of 4 percent set for domestically operating institutions. Second, all of the major banks, at some point in our sample period, received capital injections from the government. Third, even after these injections, which were meant to satisfy the BIS capital requirements, critics pointed out that the amount of capital injected was not sufficient for the major banks to satisfy the capital requirements if loans were evaluated conservatively. For these 
reasons, we think it reasonable to assume that major banks were more capital-constrained than regional financial institutions. We proceed by calculating the treatment effects for each subgroup.

The results are presented in the first two columns of Table 6. Interestingly, we observe a persistent increase in the availability of long-term loans for firms transacting with regional institutions. In contrast, for firms transacting with major banks the increase is short-lived. Moreover, the treatment effect in terms of loan availability is smaller for firms dealing with major banks.

We next further divide each of the two subsamples into quartiles depending on the bank capital ratio. The last columns of Table 6 display the results for the groups with banks having the smallest capital ratios. We find a positive and significant treatment effect, in terms of long-term loan availability, for SCG users borrowing from the least-capitalized major banks. This effect, however, is only evident in year $t$, and either disappears or becomes negative after $t+1$. In sharp contrast, there is no obvious decrease in loan availability for SCG users borrowing from regional financial institutions regardless of the bank capital level.

To summarize, although the evidence is still in favor of the availability hypothesis, the results are mixed when guaranteed loans are extended by major banks. Bank undercapitalization cancels out at least part of the increased loan availability generated by the SCG program. In the initial period, the availability of loans increases regardless of bank type or bank capital level. The increased supply of (long-term) loans, however, quickly vanishes for firms borrowing from major banks. This effect is stronger for undercapitalized major banks. This is consistent with the substitution hypothesis where undercapitalized banks withdraw non-guaranteed loans when they extend guaranteed loans, and thus, reduce their exposure to risky assets. 


\subsection{Different Loan Sizes}

Understanding when the moral hazard effect (Hypothesis 3b) dominates the investment effect (Hypothesis 3a) is crucial to our understanding about the effectiveness of credit guarantee programs. Theoretically, the moral hazard effect should be more evident in cases where firm loan demand is small, and all the loans extended to the firm by the financial institution are covered by credit guarantees. If a firm's loan demand exceeds the upper limit on guaranteed loans, which is 200 million yen for general guarantee programs and 80 million yen for SCG program loans, lenders are exposed to the firm's credit risk for the non-guaranteed portion of the loan. In this case, moral hazard is less likely as the bank has greater motivation to monitor the borrowing firm and will likely require the borrower to pledge collateral. On the other hand, if a bank's total lending to a firm is covered, the bank has no incentive to properly monitor the borrower, and moral hazard is more likely.

In order to ascertain whether the loan size matters for bank monitoring, we divide the base sample into halves, depending on a firm's level of outstanding loans in year $t-1$. The threshold value is approximately 400 million yen. ${ }^{9}$ We can then determine if program users with smaller loan amounts succumb to moral hazard more frequently than users with larger loan amounts. Specifically, we calculate treatment effects, across each subsample, for the performance variables, as well as the firm-bank relationship variables (COLL and $D O C)$.

The results, presented in Table 7, show an interesting contrast between participant firms with small loans and participant firms with large loans. Consistent with our prediction, program

\footnotetext{
${ }^{9}$ Since the threshold value of about 400 million yen exceeds the maximum amount each borrower can obtain with guaranteed loans, which is 280 million yen, we predict that the borrowers belonging to the group with larger loans outstanding are more likely to be frequently monitored by their lender. In addition, we did try other values and found that the main results are not sensitive to changes in this value.
} 
participants with a smaller amount of outstanding loans experienced a sizable and significant decrease in performance, both in terms of profitability and in terms of the probability of falling into financial distress. Furthermore, this deteriorating performance is accompanied by reduced monitoring and by a lower probability of being required to pledge collateral. In sum, we find significant and negative treatment effects for the ex-post performance of SCG users who take out smaller loans, which provides more evidence that Hypothesis (3b) (moral hazard) dominates Hypothesis (3a) (investment).

\subsection{Different Levels of Borrower Net Worth}

When discussing moral hazard in this situation, a second issue must be considered: a firm's net worth. As stated in Mishkin (1995), among others, the lower a firm's net worth, the more severe the moral hazard problem. Owners with lower equity stakes in their firm have more incentive to engage in risky investment projects. To test if net worth size affects moral hazard, we again subdivide the base sample, but this time by firms' capital ratio in year $t-1$.

The results are presented in Table 8. Consistent with theory, program users with smaller capital levels experienced a sizable and significant decrease in performance in terms of the probability of falling into financial distress. The probability of default and insolvency increases and profitability decreases at lower levels of ex-ante net worth. In contrast, at the highest ex-ante level of net worth, the probability of falling into financial distress falls. Thus, for program participants with less net worth, the moral hazard problem is exacerbated, which provides strong evidence in favor of Hypothesis (3b). Note, however, that the positive effects for SCG users with high net worth are consistent with the investment effect rather than the moral hazard effect. This is the only case that supports Hypothesis (3a) rather than Hypothesis (3b). 


\section{Conclusion}

In this paper, we empirically examined the effect of a major government credit guarantee program, Japan’s Special Credit Guarantee program, on loan availability, asset allocation, and firms' ex-post performance. The SCG program provides an excellent test case in that it was massive, temporary, and uniformly available to almost all SMEs. Using a unique panel data set of small businesses and financial institutions, we found that guarantee program participants, relative to non-participants, are met with an increase in the availability of loans. Thus, it is true that the introduction of the SCG program resulted in better procurement conditions. Also true, however, is that the increased availability of loans persisted for only a very limited period when provided by undercapitalized major banks. In this environment, major banks frequently used the SCG program to replace non-guaranteed loans with guaranteed loans in order to reduce their exposure to risky assets. This suggests that there were limitations to the extent with which the SCG program was able to stimulate bank lending when banks were heavily undercapitalized.

We also found that the ex-post performance of program users deteriorated relative to nonusers. This result is consistent with the view that credit guarantee programs exacerbate moral hazard problems in credit markets. We further found this effect to be stronger for firms financed solely by guaranteed loans. The only exception in which the investment effect dominates the moral hazard effect is when the program users had an adequate amount of net worth. A larger amount of net worth, which proxies for more sizable default costs paid by the owner-manager of a firm, induces larger managerial efforts and thus reduces the moral hazard problem.

The negative effect on profitability highlights important issues concerning the role of moral hazard, thus having a direct bearing on the legitimacy of Japan's government credit guarantee system. Given that the problem of moral hazard is greatest among firms that rely solely 
on guaranteed loans and not on non-guaranteed loans, the question arises as to how moral hazard can be mitigated, especially among small businesses.

One solution is for credit guarantee programs to more frequently require collateral and/or personal guarantees in order to strengthen the incentives for owner-managers to exert greater managerial efforts. Yet, since the end of the SCG program, Japan's credit guarantee system has moved in the opposite direction, becoming less reliant on collateral and/or personal guarantees. Aiming to facilitate the flow of funds to small and young firms with few collateralizable assets, the government has actually lowered requirements for collateral and third-party personal guarantees in the credit guarantee scheme. Our empirical results suggest that these policies may further exacerbate the moral hazard problem among participating firms in the program.

Another possible solution is to lower the interest rate that credit guarantee users in Japan are charged. Our results indicate that the loan interest rate charged to SCG users increased by more than that charged to non-users, despite the fact that financial institutions did not bear any default risks on guaranteed loans. Thus, if an appropriate mechanism could be found to provide banks with an incentive to reduce interest rates on guaranteed loans, this would decrease the incentive for borrower firms to strategically default, another symptom of moral hazard. 


\section{A Data Appendix}

To adequately evaluate the SCG program it is necessary for the data to cover at least three periods. We must first be able to calculate the probability of participating in the SCG program in period $t$ as a function of borrower and lender characteristics in period $t-1$. We can then examine how a borrower's performance develops between periods $t-1$ and $t+i$, where $i=0,1, \ldots, k$. In the case of our study, we set $k=4$ due to data availability.

The SCG program was implemented from October 1998 to March 2001. We identify three "windows" in which individual borrowers entered ${ }^{10}$ the program: (i) October 1998 to March 1999, (ii) April 1999 to March 2000, or (iii) April 2000 to March 2001. For those firms entering the program in period (i), we construct a data set for the years 1998-2003, where 1998 is year $t-1,1999$ is year $t, 2000$ is year $t+1$, and so on. For firms entering in windows (ii) and (iii) we construct the samples similarly. For example, for firms entering in (ii), the sample covers 1999-2004, where 1999 is year $t-1$, 2000 is year $t$, 2001 is year $t+1$, and so on. Finally, we concatenate the three data sets into one panel data set. The initial year of the panel is $t-1$, the second year as $t$, and the final year as $t+4$. Dummies are included in the regressions to distinguish the three different starting years.

To arrive at our final sample we implement three screens. First, observations in which one or more of the variables of interest falls into the upper or lower 0.5 percentile of the total distribution were omitted from the sample. Second, the sample is restricted to borrowers that fulfill the legal definition of SMEs. In Japan, SMEs are defined as firms with either 300 or fewer employees, or 300 million yen of registered capital or less. Finally, firms that defaulted, shut down, merged with others, or simply misreported to the credit research firm over the sample period are dropped from the sample from that point on. We are ultimately left with 10,177 observations in year $t-1$, with 2,087 SCG user firms and 8,090 non-user firms. Due to attrition, the number of observations decreases to 8,140 in year $t+4$, with 1,582 SCG user firms and 6,558 non-user firms. By concatenating observations from year $t-1$ to year $t+4$, the total number of firm-level observations is 55,588 , covering the period 1998-2005.

\footnotetext{
${ }^{10}$ By “enter” we mean first make use of the program.
} 


\section{References}

Becker, S. O. and Ichino, A., 2002 "Estimation of Average Treatment Effects Based on Propensity Scores," The Stata Journal, Vol. 2, No. 4, 358-377.

Boot, A. W. A., Thakor, A. V., and Udell, G. F., 1991, "Secured Lending and Default Risk: Equilibrium Analysis, Policy Implications and Empirical Results,” Economic Journal, Vol. 101, No. 406, 458-472.

Cowling, M., 2007, “The Role of Loan Guarantee Schemes in Alleviating Credit Rationing in the UK,” IES Working Paper, WP7.

Cowling, M. and Mitchell, P., 2003, "Is the Small Firms Loan Guarantee Scheme Hazardous for Banks or Helpful to Small Business?” Small Business Economics, Vol. 21, No. 1, 63-71.

Craig, B. R., Jackson, W. E., and Thomson, J. B., 2005, “SBA-Loan Guarantees and Local Economic Growth,” Federal Reserve Bank of Cleveland Working Paper, 05-03.

Craig, B. R., Jackson, W. E., and Thomson, J. B., 2007, “On Government Intervention in the Small-Firm Credit Market and its Effect on Economic Performance,” Federal Reserve Bank of Cleveland Working Paper, 07-02.

DeMeza D. and Webb, D. C., 1987, “Too Much Investment: A Problem of Asymmetric Information,” The Quarterly Journal of Economics, Vol. 102, No. 2, 281-292.

Diamond, D., 2001, “Should Japanese Banks be Recapitalized?” Monetary and Economic Studies, Vol. 19, No. 2, 1-19.

Freixas, X. and Rochet, J.-C., 1997, Microeconomics of Banking, Cambridge, Massachusetts: MIT Press.

Gale, W. G., 1990, “Federal Lending and the Market for Credit,” Journal of Public Economics, Vol. 42, No. 2, 177-193.

Gale, W. G., 1991, “Economic Effects of Federal Credit Programs,” American Economic Review, Vol. 81, No. 1, 133-152.

Glennon, D. and Nigro, P., 2005, "Measuring the Default Risk of Small Business Loans: A Survival Analysis Approach,” Journal of Money, Credit, and Banking, Vol. 37, No. 5, 923-947.

Green, A., 2003, “Credit Guarantee Schemes for Small Enterprises: An Effective Instrument to Promote Private Sector-Led Growth?” SME Technical Working Paper Series, No.10, UNIDO.

Hancock, D., Peek, J., and Wilcox, J., 2008, “The Repercussions on Small Banks and Small Businesses of Procyclical Bank Capital and Countercyclical Loan Guarantees,” Paper presented at the World Bank Conference on Partial Credit Guarantees, March 13-14, 2008.

Hancock, D. and Wilcox, J., 1998, “The 'Credit Crunch' and the Availability of Credit to Small Businesses,” Journal of Banking and Finance, Vol. 22, Nos. 6-8, 983-1014.

Heckman, J., Ichimura, H., Smith, J., and Todd, P., 1998, “Characterizing Selection Bias Using Experimental Data,” Econometrica, Vol. 66, No.5, 1017-1098.

Honohan, P., 2008, “Partial Credit Guarantees: Principles and Practice,” Paper presented at the World Bank Conference on Partial Credit Guarantees, March 13-14, 2008. 
Hoshi, T. and Kashyap, A. K., 2004, “Japan’s Financial Crisis and Economic Stagnation,” Journal of Economic Perspectives, Vol. 18, No. 1, 3-26.

Innes, R., 1991, "Investment and Government Intervention in Credit Markets When There is Asymmetric Information,” Journal of Public Economics, Vol. 46, No. 3, 347-381.

Kang, J. W., and Heshmati, A., 2007, "Effect of Credit Guarantee Policy on Survival and Performance of SMEs in Republic of Korea” (sic), Small Business Economics, Online publication.

Konishi, M., and Hasebe, K., 2002, "Koteki Shinnyohosho no Seisaku Koka (Effects of Public Credit Guarantees),” The Hitotsubashi Review, Vol. 5, 36-47 (in Japanese).

Li, W., 1998, “Government Loan, Guarantee, and Grant Programs: An Evaluation,” Federal Reserve Bank of Richmond, Economic Quarterly, Vol. 84, No. 4, 25-51.

Mankiw, G. N., 1986, “The Allocation of Credit and Financial Collapse,” Quarterly Journal of Economics, Vol. 101, No. 3, 455-470.

Matsuura, K. and Hori, M., 2003, “Tokubetsu Shinyo Hosho to Chusho Kigyo Keiei no Sai Kochiku,” (Special Credit Guarantee and Restructuring of Small Firms), ESRI Discussion Paper Series, No. 50, (in Japanese).

Motonishi, T. and Yoshikawa H., 1999, "Causes of the Long Stagnation of Japan during the 1990s: Financial or Real?” Journal of the Japanese and International Economies, Vol. 13, No. 3, 181-200.

Ogawa, K., 2003, “Financial Distress and Employment: The Japanese Case in the 90s,” NBER Working Paper, No. 9646.

Riding, A. L. and Haines, G. Jr., 2001, "Loan Guarantees: Costs of Default and Benefits to Small Firms,” Journal of Business Venturing, Vol. 16, No. 6, 595-612.

Riding, A. L., Madill, J., and Haines, G. Jr., 2006, “Incrementality of SME Loan Guarantees,” Small Business Economics, Vol. 29, Nos. 1-2, 47-61.

Rosenbaum, P. P., and Rubin, D. B., 1983, “The Central Role of the Propensity Score in Observational Studies for Causal Effects,” Biometrika, Vol. 70, No. 1, 41-55.

Smith, B. D. and Stutzer, M. J., 1989, “Credit Rationing and Government Loan Programs: A Welfare Analysis,” AREUEA Journal, Vol. 17, No. 2, 177-193.

Stiglitz, J., and Weiss, A., 1981 “Credit Rationing in Markets with Imperfect Information,” American Economic Review, Vol. 71, No. 3, 93-410.

Vogel, R. C., Adams, D. W., 1997, “Costs and Benefits of Loan Guarantee Programs,” The Financier, Vol. 4, Nos. 1-2, 22-29.

Wilcox, J. A. and Yasuda, Y., 2008, “Do Government Loan Guarantees Lower, or Raise, Banks’ NonGuaranteed Lending? Evidence from Japanese Banks," Paper presented at the World Bank Conference on Partial Credit Guarantees, March 13-14, 2008.

Williamson, S. D., 1994, “Do Informational Frictions Justify Federal Credit Programs?” Journal of Money, Credit and Banking, Vol. 26, No. 3, 523-544. 
Woo, D., 2003, “In Search of ‘Capital Crunch’: Supply Factors Behind the Credit Slowdown in Japan,” Journal of Money, Credit and Banking, Vol. 35, No. 6, Part 1, 1019-1038.

Wooldridge, J. M., 2002, Econometric Analysis of Cross Section and Panel Data, Cambridge, Massachusetts: MIT Press.

Zecchini, S. and Ventura, M., 2007, “The Impact of Public Guarantees on Credit to SMEs,” Small Business Economics, Online publication. 


\section{Table 1: Definitions of Variables}

\begin{tabular}{|c|c|}
\hline \multicolumn{2}{|l|}{ Use of SCG program } \\
\hline$S C G$ & 1 if the borrower uses the SCG program, 0 otherwise. \\
\hline \multicolumn{2}{|l|}{ Borrower } \\
\hline \multicolumn{2}{|l|}{ Characteristics } \\
\hline \multicolumn{2}{|l|}{ Availability } \\
\hline LOANRATIO & Ratio of loans (long-term, short-term, bills discounted) to total assets. \\
\hline LONGRATIO & $\begin{array}{l}\text { Ratio of long-term loans (loans with more than } 1 \text { year maturity) to total } \\
\text { assets. }\end{array}$ \\
\hline SHORTRATIO & $\begin{array}{l}\text { Ratio of short-term loans (loans with less than or equal to } 1 \text { year maturity) to } \\
\text { total assets. }\end{array}$ \\
\hline MATURITY & $\begin{array}{l}\text { Ratio of long-term loans to the combined value of long-term and short term } \\
\text { loans. }\end{array}$ \\
\hline RATE & Ratio of interest payments to amount of loans. \\
\hline \multicolumn{2}{|l|}{ Allocation } \\
\hline CASH & Ratio of cash and deposits to total assets. \\
\hline WCAP & Ratio of working capital to total assets. \\
\hline FCAP & Ratio of fixed tangible assets to total asset. \\
\hline \multicolumn{2}{|l|}{ Performance } \\
\hline$R O A$ & $\begin{array}{l}\text { Ratio of business profits to total asset. Business profits are before interest } \\
\text { payments and tax. }\end{array}$ \\
\hline ICOVER & Ratio of business profits to interest payments. \\
\hline$C A P \_N G$ & 1 if the capital ratio is negative, 0 otherwise. \\
\hline ICOV̄ER_SM & 1 if ICOVER is less than one, 0 otherwise. \\
\hline DEFAULT & 1 if the borrower defaults, 0 otherwise. \\
\hline \multicolumn{2}{|l|}{ General } \\
\hline LnAGE & Log of the age of the borrowing firm. \\
\hline LnLOAN & Log of loans outstanding. \\
\hline YEARx & 1 if the observation is recorded in year $x, 0$ otherwise. $x=1999,2000,2001$. \\
\hline \multicolumn{2}{|l|}{ Bank characteristics } \\
\hline MAJOR & $\begin{array}{l}1 \text { if the lender of the borrowing firm is either a city bank, a trust bank, or a } \\
\text { long-term credit bank, } 0 \text { otherwise. }\end{array}$ \\
\hline REGIONAL & $\begin{array}{l}1 \text { if the lender of the borrowing firm is either a regional bank, a second-tier } \\
\text { regional bank, a shinkin bank, or a credit union, } 0 \text { otherwise. }\end{array}$ \\
\hline BANKCAP & Bank’s capital ratio. \\
\hline \multicolumn{2}{|l|}{ Relationship } \\
\hline LnRELYEAR & $\begin{array}{l}\text { Log of the number of years the borrower firm has been transacting with its } \\
\text { main bank. }\end{array}$ \\
\hline NUMBANK & Number of banks the borrower firm is transacting with. \\
\hline $\mathrm{DOC}$ & $\begin{array}{l}\text { Index variable indicating the frequency of document submissions to the } \\
\text { borrower's main bank: 1: annually, 2: semi-annually, 3: quarterly, 4: once } \\
\text { every 1-2 months. }\end{array}$ \\
\hline COLL & 1 if the borrower pledges collateral to the main bank, 0 otherwise. \\
\hline
\end{tabular}


Table 2: Summary Statistics

\begin{tabular}{|c|c|c|c|}
\hline & $\begin{array}{c}\text { All } \\
\text { Mean } \\
\text { Std. Dev. }\end{array}$ & $\begin{array}{c}S C G=1 \\
\text { Mean } \\
\text { Std. Dev. }\end{array}$ & $\begin{array}{c}S C G=0 \\
\text { Mean } \\
\text { Std. Dev. }\end{array}$ \\
\hline \multicolumn{4}{|l|}{ Availability } \\
\hline LOANRATIO & $\begin{array}{r}0.394 \\
(0.231)\end{array}$ & $\begin{array}{r}0.498 \\
(0.211)\end{array}$ & $\begin{array}{r}0.367 \\
(0.229)\end{array}$ \\
\hline LONGRATIO & $\begin{array}{r}0.250 \\
(0.187)\end{array}$ & $\begin{array}{r}0.317 \\
(0.189)\end{array}$ & $\begin{array}{r}0.231 \\
(0.183)\end{array}$ \\
\hline SHORTRATIO & $\begin{array}{r}0.189 \\
(0.158)\end{array}$ & $\begin{array}{r}0.212 \\
(0.161)\end{array}$ & $\begin{array}{r}0.183 \\
(0.157)\end{array}$ \\
\hline MATURITY & $\begin{array}{r}0.563 \\
(0.328)\end{array}$ & $\begin{array}{r}0.616 \\
(0.283)\end{array}$ & $\begin{array}{r}0.549 \\
(0.337)\end{array}$ \\
\hline RATE & $\begin{array}{r}0.027 \\
(0.018)\end{array}$ & $\begin{array}{r}0.030 \\
(0.016)\end{array}$ & $\begin{array}{r}0.027 \\
(0.018)\end{array}$ \\
\hline \multicolumn{4}{|l|}{ Allocation } \\
\hline $\mathrm{CASH}$ & $\begin{array}{r}0.171 \\
(0.120)\end{array}$ & $\begin{array}{r}0.162 \\
(0.109)\end{array}$ & $\begin{array}{r}0.174 \\
(0.123)\end{array}$ \\
\hline WCAP & $\begin{array}{r}0.132 \\
(0.161)\end{array}$ & $\begin{array}{r}0.126 \\
(0.177)\end{array}$ & $\begin{array}{r}0.133 \\
(0.157)\end{array}$ \\
\hline FCAP & $\begin{array}{r}0.308 \\
(0.196)\end{array}$ & $\begin{array}{r}0.299 \\
(0.199)\end{array}$ & $\begin{array}{r}0.310 \\
(0.195)\end{array}$ \\
\hline \multicolumn{4}{|l|}{ Performance } \\
\hline$R O A$ & $\begin{array}{r}0.023 \\
(0.053)\end{array}$ & $\begin{array}{r}0.015 \\
(0.051)\end{array}$ & $\begin{array}{r}0.026 \\
(0.054)\end{array}$ \\
\hline ICOVER & $\begin{array}{r}8.847 \\
(48.593)\end{array}$ & $\begin{array}{r}1.697 \\
(8.030)\end{array}$ & $\begin{array}{r}10.692 \\
(54.197)\end{array}$ \\
\hline$R O A \_N G$ & $\begin{array}{r}0.213 \\
(0.409)\end{array}$ & $\begin{array}{r}0.262 \\
(0.440)\end{array}$ & $\begin{array}{r}0.200 \\
(0.400)\end{array}$ \\
\hline$C A P \_N G$ & $\begin{array}{r}0.045 \\
(0.208)\end{array}$ & $\begin{array}{r}0.076 \\
(0.265)\end{array}$ & $\begin{array}{r}0.037 \\
(0.189)\end{array}$ \\
\hline ICOVER_SM & $\begin{array}{r}0.360 \\
(0.480)\end{array}$ & $\begin{array}{r}0.494 \\
(0.500)\end{array}$ & $\begin{array}{r}0.325 \\
(0.468)\end{array}$ \\
\hline DEFAULT & $\begin{array}{r}0.001 \\
(0.033)\end{array}$ & $\begin{array}{r}0.002 \\
(0.044)\end{array}$ & $\begin{array}{r}0.001 \\
(0.029)\end{array}$ \\
\hline \multicolumn{4}{|l|}{ General } \\
\hline Ln AGE & $\begin{array}{r}3.376 \\
(0.574)\end{array}$ & $\begin{array}{r}3.279 \\
(0.589)\end{array}$ & $\begin{array}{r}3.401 \\
(0.568)\end{array}$ \\
\hline Ln LOAN & $\begin{array}{l}12.781 \\
(1.593)\end{array}$ & $\begin{array}{l}12.821 \\
(1.376)\end{array}$ & $\begin{array}{l}12.771 \\
(1.644)\end{array}$ \\
\hline YEAR 1999 & $\begin{array}{r}0.444 \\
(0.497)\end{array}$ & $\begin{array}{r}0.693 \\
(0.461)\end{array}$ & $\begin{array}{r}0.379 \\
(0.485)\end{array}$ \\
\hline YEAR 2000 & $\begin{array}{r}0.314 \\
(0.464)\end{array}$ & $\begin{array}{r}0.219 \\
(0.414)\end{array}$ & $\begin{array}{r}0.338 \\
(0.473)\end{array}$ \\
\hline YEAR 2001 & $\begin{array}{r}0.243 \\
(0.429)\end{array}$ & $\begin{array}{r}0.088 \\
(0.283)\end{array}$ & $\begin{array}{r}0.283 \\
(0.450)\end{array}$ \\
\hline \multicolumn{4}{|l|}{ Bank characteristics } \\
\hline MAJOR & $\begin{array}{r}0.329 \\
(0.470)\end{array}$ & $\begin{array}{r}0.324 \\
(0.468)\end{array}$ & $\begin{array}{r}0.331 \\
(0.471)\end{array}$ \\
\hline REGIONAL & $\begin{array}{r}0.671 \\
(0.470)\end{array}$ & $\begin{array}{r}0.676 \\
(0.468)\end{array}$ & $\begin{array}{r}0.669 \\
(0.471)\end{array}$ \\
\hline BANKCAP & $\begin{array}{r}0.100 \\
(0.020)\end{array}$ & $\begin{array}{r}0.096 \\
(0.019)\end{array}$ & $\begin{array}{r}0.101 \\
(0.020)\end{array}$ \\
\hline \multicolumn{4}{|l|}{ Relationship } \\
\hline Ln RELYEAR & $\begin{array}{r}3.196 \\
(0.710)\end{array}$ & $\begin{array}{r}3.048 \\
(0.787)\end{array}$ & $\begin{array}{r}3.235 \\
(0.683)\end{array}$ \\
\hline NUMBANK & $\begin{array}{r}4.027 \\
(3.362)\end{array}$ & $\begin{array}{r}4.457 \\
(3.308)\end{array}$ & $\begin{array}{r}3.916 \\
(3.367)\end{array}$ \\
\hline$D O C$ & $\begin{array}{r}1.762 \\
(1.067)\end{array}$ & $\begin{array}{r}2.085 \\
(1.239)\end{array}$ & $\begin{array}{r}1.719 \\
(1.035)\end{array}$ \\
\hline$C O L L$ & $\begin{array}{r}0.784 \\
(0.412)\end{array}$ & $\begin{array}{r}0.896 \\
(0.305)\end{array}$ & $\begin{array}{r}0.769 \\
(0.422)\end{array}$ \\
\hline $\mathrm{N}$ & 10,177 & 2,087 & 8,090 \\
\hline
\end{tabular}

Note 1: Variables are measured in year $t-1$.

Note 2: DEFAULT, DOC, and COLL do not have values for year $t-1$ and the values shown are for year $t+1$. 
Table 3: Probit Estimation

\begin{tabular}{|c|c|c|c|}
\hline \multicolumn{4}{|l|}{ Dependent variable: SCG } \\
\hline & Coefficient & d. Error & \\
\hline \multicolumn{4}{|l|}{ Availability } \\
\hline LOANRATIO & 1.937 & $(0.098)$ & $* * *$ \\
\hline MATURITY & 0.341 & $(0.054)$ & $* * *$ \\
\hline RATE & 5.017 & $(0.888)$ & *** \\
\hline \multicolumn{4}{|l|}{ Allocation } \\
\hline $\mathrm{CASH}$ & -0.655 & $(0.156)$ & *** \\
\hline WCAP & -0.573 & $(0.107)$ & $* * *$ \\
\hline FCAP & -1.060 & $(0.104)$ & $* * *$ \\
\hline \multicolumn{4}{|l|}{ Performance } \\
\hline$R O A$ & 1.048 & $(0.460)$ & ** \\
\hline ICOVER & -0.008 & $(0.002)$ & $* * *$ \\
\hline$R O A \_N G$ & -0.024 & $(0.053)$ & \\
\hline CAP_NG & -0.312 & $(0.074)$ & $* * *$ \\
\hline ICOVER_SM & 0.245 & $(0.045)$ & $* * *$ \\
\hline \multicolumn{4}{|l|}{ General } \\
\hline Ln LOAN & -0.123 & $(0.016)$ & $* * *$ \\
\hline Ln $A G E$ & 0.084 & $(0.035)$ & ** \\
\hline YEAR1999 & 0.518 & $(0.039)$ & *** \\
\hline YEAR2001 & -0.276 & $(0.050)$ & $* * *$ \\
\hline \multicolumn{4}{|l|}{ Bank } \\
\hline BANKCAP & -6.692 & (2.574) & $* * *$ \\
\hline REGIONAL & -0.715 & $(0.276)$ & $* * *$ \\
\hline REGIONAL *BANKCAP & 5.742 & (2.679) & $* *$ \\
\hline \multicolumn{4}{|l|}{ Relationship } \\
\hline Ln RELYEAR & -0.127 & $(0.027)$ & $* * *$ \\
\hline NUMBANK & 0.027 & $(0.005)$ & $* * *$ \\
\hline CONS & 0.370 & $(0.388)$ & \\
\hline Industrial Dummies & Yes & & \\
\hline $\mathrm{N}$ & 10,177 & & \\
\hline Pseudo R-sq & 0.165 & & \\
\hline Log Likelihood & $-4,313.121$ & & \\
\hline
\end{tabular}

Note 1: ***,**,* indicate a significance level of $1 \%, 5 \%$, and $10 \%$, respectively.

Note 2: The dependent variable is measured in year $t$, while explanatory variables are for year $t-1$. 
Table 4: Treatment Effect (Base Case)

\begin{tabular}{|c|c|c|c|c|c|c|c|c|c|c|c|}
\hline & & Treatment & Control & Diff. in I & $\overline{\text { Diff. }}$ & & & Treatment & Control & Diff. in $\mathrm{I}$ & $\overline{\text { Diff. }}$ \\
\hline \multirow[t]{6}{*}{ LOANRATIO } & $t-1$ & 0.498 & 0.500 & & & \multirow[t]{6}{*}{$R O A$} & $t-1$ & 0.015 & 0.013 & & \\
\hline & $t$ & 0.516 & 0.497 & 0.021 & $* * *$ & & $t$ & 0.014 & 0.016 & -0.004 & $* * *$ \\
\hline & $t+1$ & 0.509 & 0.487 & 0.023 & $* * *$ & & $t+1$ & 0.018 & 0.021 & -0.004 & $* * *$ \\
\hline & $t+2$ & 0.502 & 0.477 & 0.025 & $* * *$ & & $t+2$ & 0.018 & 0.021 & -0.005 & $* * *$ \\
\hline & $t+3$ & 0.503 & 0.472 & 0.031 & $* * *$ & & $t+3$ & 0.019 & 0.017 & 0.000 & \\
\hline & $t+4$ & 0.494 & 0.459 & 0.037 & $* * *$ & & $t+4$ & 0.023 & 0.021 & -0.002 & \\
\hline \multirow[t]{6}{*}{ LONGRATIO } & $t-1$ & 0.317 & 0.322 & & & \multirow{2}{*}{\multicolumn{2}{|c|}{$p(D E F A U L T=1)$}} & & & & \\
\hline & $t$ & 0.343 & 0.326 & 0.022 & $* * *$ & & & & & & \\
\hline & $t+1$ & 0.336 & 0.321 & 0.021 & *** & & $t+1$ & 0.002 & 0.001 & 0.001 & \\
\hline & $t+2$ & 0.325 & 0.310 & 0.020 & *** & & $t+2$ & 0.005 & 0.002 & 0.003 & * \\
\hline & $t+3$ & 0.326 & 0.314 & 0.015 & *** & & $t+3$ & 0.026 & 0.011 & 0.015 & $* * *$ \\
\hline & $t+4$ & 0.320 & 0.307 & 0.014 & $* * *$ & & $t+4$ & 0.019 & 0.016 & 0.003 & \\
\hline \multirow[t]{6}{*}{ SHORTRATIO } & $t-1$ & 0.212 & 0.225 & & & \multirow[t]{6}{*}{$p\left(C A P \_N G=1\right)$} & $t-1$ & 0.076 & 0.071 & & \\
\hline & $t$ & 0.208 & 0.221 & -0.004 & * & & $t$ & 0.081 & 0.076 & 0.000 & \\
\hline & $t+1$ & 0.211 & 0.216 & 0.001 & & & $t+1$ & 0.087 & 0.074 & 0.005 & \\
\hline & $t+2$ & 0.213 & 0.220 & 0.002 & & & $t+2$ & 0.074 & 0.063 & 0.009 & \\
\hline & $t+3$ & 0.215 & 0.220 & 0.004 & & & $t+3$ & 0.078 & 0.056 & 0.024 & $* * *$ \\
\hline & $t+4$ & 0.211 & 0.214 & 0.007 & & & $t+4$ & 0.076 & 0.052 & 0.031 & $* * *$ \\
\hline \multirow[t]{6}{*}{ RATE } & $t-1$ & 0.030 & 0.030 & & & \multicolumn{2}{|c|}{$p\left(I C O V E R \_S M=t-1\right.$} & 0.494 & 0.507 & & \\
\hline & $t$ & 0.028 & 0.028 & 0.001 & $* * *$ & & $t$ & 0.493 & 0.436 & 0.073 & *** \\
\hline & $t+1$ & 0.028 & 0.027 & 0.002 & $* * *$ & & $t+1$ & 0.435 & 0.394 & 0.055 & $* * *$ \\
\hline & $t+2$ & 0.028 & 0.026 & 0.002 & *** & & $t+2$ & 0.423 & 0.388 & 0.055 & *** \\
\hline & $t+3$ & 0.027 & 0.025 & 0.003 & $* * *$ & & $t+3$ & 0.420 & 0.412 & 0.029 & $*$ \\
\hline & $t+4$ & 0.027 & 0.025 & 0.003 & $* * *$ & & $t+4$ & 0.374 & 0.363 & 0.040 & $* *$ \\
\hline \multirow[t]{6}{*}{ CASH } & $t-1$ & 0.162 & 0.163 & & & & & & & & \\
\hline & $t$ & 0.165 & 0.166 & 0.000 & & & & & & & \\
\hline & $t+1$ & 0.161 & 0.164 & -0.001 & & & & & & & \\
\hline & $t+2$ & 0.162 & 0.162 & 0.000 & & & & & & & \\
\hline & $t+3$ & 0.159 & 0.158 & 0.001 & & & & & & & \\
\hline & $t+4$ & 0.158 & 0.155 & 0.002 & & & & & & & \\
\hline \multirow[t]{6}{*}{ WCAP } & $t-1$ & 0.126 & 0.123 & & & & & & & & \\
\hline & $t$ & 0.132 & 0.126 & 0.003 & & & & & & & \\
\hline & $t+1$ & 0.128 & 0.129 & -0.004 & & & & & & & \\
\hline & $t+2$ & 0.131 & 0.132 & -0.002 & & & & & & & \\
\hline & $t+3$ & 0.137 & 0.135 & 0.005 & & & & & & & \\
\hline & $t+4$ & 0.142 & 0.133 & 0.010 & $* * *$ & & & & & & \\
\hline \multirow[t]{6}{*}{ FCAP } & $t-1$ & 0.299 & 0.306 & & & & & & & & \\
\hline & $t$ & 0.300 & 0.306 & 0.003 & * & & & & & & \\
\hline & $t+1$ & 0.303 & 0.308 & 0.004 & * & & & & & & \\
\hline & $t+2$ & 0.305 & 0.309 & 0.003 & & & & & & & \\
\hline & $t+3$ & 0.314 & 0.318 & 0.002 & & & & & & & \\
\hline & $t+4$ & 0.311 & 0.322 & -0.003 & & & & & & & \\
\hline
\end{tabular}

Note $1: * * *, * *, *$ indicate a significance level of $1 \%, 5 \%$, and $10 \%$, respectively.

Note 2: The treatment effect for each variable is shown in the "Diff. in Diff." column. For example, the treatment effect for LOANRATIO is defined as $\Delta^{2}$ LOANRATIO $_{t+i}=\left(\right.$ LOANRATIO $_{t+i}^{\text {Treatment }}-$ LOANRATIO $\left._{t-1}^{\text {Treatment }}\right)-\left(\right.$ LOANRATIO $_{t+i}^{\text {Conrol }}-$ LOANRATIO $\left._{t-1}^{\text {Control }}\right)$

The only exception is the variable $p(D E F A U L T=1)$. Since the variable starts from $t+1$ and not from $t-1$, we define its treatment effect as $\Delta p_{t+i}(D E F A U L T=1)=p_{t+i}^{\text {Treatment }}(D E F A U L T=1)-p_{t+i}^{\text {Conrol }}(D E F A U L T=1)$

Note 3: For each variable, the number of observations differs between $t-1$ and $t+i$ due to the attrition of observations. 
Table 5: Treatment Effect (Base Case with Other Matching Techniques)

\begin{tabular}{|c|c|c|c|c|c|c|c|c|c|c|c|c|c|c|c|}
\hline & & \multicolumn{6}{|c|}{ 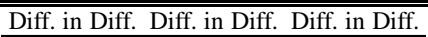 } & & \multirow[b]{3}{*}{$t-1$} & \multicolumn{6}{|c|}{ Diff. in Diff. Diff. in Diff. Diff. in Diff. } \\
\hline & & \multicolumn{2}{|c|}{$\mathrm{k}=10$} & \multicolumn{2}{|c|}{ Kernel } & \multicolumn{2}{|c|}{ Radius } & \multirow[b]{2}{*}{$R O A$} & & \multicolumn{2}{|c|}{$\mathrm{k}=10$} & \multicolumn{2}{|c|}{ Kernel } & \multicolumn{2}{|c|}{ Radius } \\
\hline \multirow[t]{6}{*}{ LOANR } & $t-1$ & & & & & & & & & & & & & & \\
\hline & $t$ & 0.021 & $* * *$ & 0.021 & $* * *$ & 0.021 & $* * *$ & & $t$ & -0.004 & $* * *$ & -0.004 & $* * *$ & -0.005 & $* * *$ \\
\hline & $t+1$ & 0.023 & $* * *$ & 0.022 & $* * *$ & 0.023 & $* * *$ & & $t+1$ & -0.004 & $* * *$ & -0.003 & $* * *$ & -0.004 & $* * *$ \\
\hline & $t+2$ & 0.028 & $* * *$ & 0.026 & $* * *$ & 0.025 & $* * *$ & & $t+2$ & -0.005 & $* * *$ & -0.004 & $* * *$ & -0.005 & $* * *$ \\
\hline & $t+3$ & 0.035 & $* * *$ & 0.033 & $* * *$ & 0.033 & $* * *$ & & $t+3$ & -0.002 & & -0.001 & & -0.001 & \\
\hline & $t+4$ & 0.038 & $* * *$ & 0.037 & $* * *$ & 0.035 & $* * *$ & & $t+4$ & -0.002 & & -0.001 & & -0.001 & \\
\hline \multicolumn{8}{|c|}{ LONGRATIO t-1 } & \multicolumn{8}{|c|}{$p(D E F A U L T=1)$} \\
\hline & $t$ & 0.021 & $* * *$ & 0.021 & $* * *$ & 0.021 & $* * *$ & & & & & & & & \\
\hline & $t+1$ & 0.021 & $* * *$ & 0.022 & $* * *$ & 0.023 & $* * *$ & & $t+1$ & 0.001 & & 0.002 & & 0.002 & $*$ \\
\hline & $t+2$ & 0.022 & $* * *$ & 0.022 & $* * *$ & 0.024 & $* * *$ & & $t+2$ & 0.002 & & 0.002 & & 0.002 & \\
\hline & $t+3$ & 0.018 & $* * *$ & 0.018 & $* * *$ & 0.018 & $* * *$ & & $t+3$ & 0.016 & $* * *$ & 0.016 & $* * *$ & 0.015 & $* * *$ \\
\hline & $t+4$ & 0.015 & $* * *$ & 0.015 & $* * *$ & 0.016 & $* * *$ & & $t+4$ & 0.002 & & 0.002 & & 0.001 & \\
\hline \multicolumn{8}{|c|}{ SHORTRATIC $t-1$} & \multicolumn{8}{|c|}{$p\left(C A P \_N G=1 t-1\right.$} \\
\hline & $t$ & -0.003 & & -0.004 & $* *$ & -0.005 & $* *$ & & $t$ & 0.001 & & 0.000 & & 0.001 & \\
\hline & $t+1$ & 0.000 & & -0.003 & & -0.005 & $*$ & & $t+1$ & 0.006 & & 0.004 & & 0.005 & \\
\hline & $t+2$ & 0.003 & & -0.001 & & -0.002 & & & $t+2$ & 0.008 & & 0.006 & & 0.007 & \\
\hline & $t+3$ & 0.006 & & 0.002 & & 0.001 & & & $t+3$ & 0.022 & $* * *$ & 0.018 & $* * *$ & 0.020 & $* * *$ \\
\hline & $t+4$ & 0.008 & $* *$ & 0.005 & & 0.004 & & & $t+4$ & 0.030 & $* * *$ & 0.026 & $* * *$ & 0.025 & $* * *$ \\
\hline \multirow[t]{6}{*}{ RATE } & $t-1$ & & & & & & & \multicolumn{8}{|c|}{ p(ICOVER_SI t-1 } \\
\hline & $t$ & 0.001 & $*$ & 0.000 & & 0.000 & & & $t$ & 0.071 & $* * *$ & 0.065 & $* * *$ & 0.071 & $* * *$ \\
\hline & $t+1$ & 0.001 & $* * *$ & 0.001 & $* * *$ & 0.001 & $* * *$ & & $t+1$ & 0.051 & $* * *$ & 0.042 & $* * *$ & 0.051 & $* * *$ \\
\hline & $t+2$ & 0.002 & $* * *$ & 0.002 & $* * *$ & 0.002 & $* * *$ & & $t+2$ & 0.049 & $* * *$ & 0.044 & $* * *$ & 0.049 & $* * *$ \\
\hline & $t+3$ & 0.003 & $* * *$ & 0.002 & $* * *$ & 0.002 & $* * *$ & & $t+3$ & 0.039 & $* *$ & 0.034 & $* *$ & 0.034 & $* *$ \\
\hline & $t+4$ & 0.003 & $* * *$ & 0.003 & $* * *$ & 0.003 & $* * *$ & & $t+4$ & 0.040 & $* *$ & 0.025 & $*$ & 0.031 & $* *$ \\
\hline \multirow[t]{6}{*}{$\mathrm{CASH}$} & $t-1$ & & & & & & & & & & & & & & \\
\hline & $t$ & -0.001 & & -0.001 & & -0.001 & & & & & & & & & \\
\hline & $t+1$ & -0.001 & & -0.001 & & -0.001 & & & & & & & & & \\
\hline & $t+2$ & 0.000 & & 0.000 & & 0.000 & & & & & & & & & \\
\hline & $t+3$ & 0.000 & & 0.000 & & 0.000 & & & & & & & & & \\
\hline & $t+4$ & 0.002 & & 0.001 & & 0.001 & & & & & & & & & \\
\hline \multirow[t]{6}{*}{ WCAP } & $t-1$ & & & & & & & & & & & & & & \\
\hline & $t$ & 0.004 & $*$ & 0.003 & & 0.003 & & & & & & & & & \\
\hline & $t+1$ & -0.003 & & -0.003 & & -0.003 & & & & & & & & & \\
\hline & $t+2$ & 0.000 & & -0.001 & & -0.002 & & & & & & & & & \\
\hline & $t+3$ & 0.006 & $*$ & 0.003 & & 0.003 & & & & & & & & & \\
\hline & $t+4$ & 0.010 & $* * *$ & 0.006 & $* *$ & 0.006 & $*$ & & & & & & & & \\
\hline FCAP & $t-1$ & & & & & & & & & & & & & & \\
\hline & $t$ & 0.002 & $* *$ & 0.003 & $* * *$ & 0.003 & $* * *$ & & & & & & & & \\
\hline & $t+1$ & 0.003 & $*$ & 0.004 & $* *$ & 0.004 & $* *$ & & & & & & & & \\
\hline & $t+2$ & 0.003 & & 0.004 & $*$ & 0.005 & $* *$ & & & & & & & & \\
\hline & $t+3$ & 0.001 & & 0.003 & & 0.003 & & & & & & & & & \\
\hline & $t+4$ & -0.004 & & -0.002 & & -0.002 & & & & & & & & & \\
\hline
\end{tabular}

Note $1: * * *, * *, *$ indicate a significance level of $1 \%, 5 \%$, and $10 \%$, respectively.

Note 2: The treatment effect for each variable is shown in the "Diff. in Diff." column. For example, the treatment effect for LOANRATIO is defined as $\Delta^{2}$ LOANRATIO $_{t+i}=\left(\right.$ LOANRATIO $_{t+i}^{\text {Treatment }}-$ LOANRATIO $\left._{t-1}^{\text {Treatment }}\right)-\left(\right.$ LOANRATIO $_{t+i}^{\text {Control }}-$ LOANRATIO $\left._{t-1}^{\text {Control }}\right)$

The only exception is the variable $p(D E F A U L T=1)$. Since the variable starts from $t+1$ and not from $t-1$, we define its treatment effect as $\Delta p_{t+i}(D E F A U L T=1)=p_{t+i}^{\text {Treatment }}(D E F A U L T=1)-p_{t+i}^{\text {Control }}(D E F A U L T=1)$

Note 3: For each variable, the number of observations differs between $t-1$ and $t+i$ due to the attrition of observations. 
Table 6: Treatment Effect (Effect of Bank Capital on Loan Availability)

\begin{tabular}{|c|c|c|c|c|c|c|c|c|c|}
\hline & & \multicolumn{2}{|c|}{ Diff. in Diff. } & \multicolumn{2}{|c|}{ Diff. in Diff. } & \multicolumn{2}{|c|}{ Diff. in Diff. } & \multicolumn{2}{|c|}{ Diff. in Diff. } \\
\hline & & \multicolumn{2}{|l|}{$M A J O R=1$} & \multicolumn{2}{|l|}{$\begin{array}{l}\text { REGIONAL } \\
=1\end{array}$} & \multicolumn{2}{|l|}{$M A J O R=1$} & \multicolumn{2}{|l|}{$\begin{array}{l}\text { REGIONAL } \\
\quad=1\end{array}$} \\
\hline & & & & & & $\begin{array}{l}\text { First quartile } \\
\text { (Smallest) }\end{array}$ & & $\begin{array}{l}\text { First quartile } \\
\text { (Smallest) }\end{array}$ & \\
\hline \multirow[t]{5}{*}{ LOANRATIO } & $t$ & 0.018 & **** & 0.023 & $* * *$ & 0.019 & $* *$ & 0.020 & $* * *$ \\
\hline & $t+1$ & 0.018 & $* * *$ & 0.026 & $* * *$ & 0.018 & $*$ & 0.024 & $* * *$ \\
\hline & $t+2$ & 0.022 & $* * *$ & 0.026 & $* * *$ & 0.017 & & 0.022 & $* * *$ \\
\hline & $t+3$ & 0.024 & $* * *$ & 0.034 & $* * *$ & 0.005 & & 0.027 & $* * *$ \\
\hline & $t+4$ & 0.018 & $* *$ & 0.047 & $* * *$ & 0.009 & & 0.045 & $* * *$ \\
\hline \multirow[t]{5}{*}{ LONGRATIO } & $t$ & 0.014 & $* * *$ & 0.026 & $* * *$ & 0.018 & $* *$ & 0.023 & $* * *$ \\
\hline & $t+1$ & 0.012 & $* *$ & 0.025 & $* * *$ & -0.005 & & 0.022 & $* * *$ \\
\hline & $t+2$ & 0.011 & & 0.024 & $* * *$ & -0.014 & & 0.026 & $* * *$ \\
\hline & $t+3$ & 0.007 & & 0.019 & $* * *$ & -0.008 & & 0.012 & \\
\hline & $t+4$ & -0.002 & & 0.023 & $* * *$ & -0.010 & & 0.018 & $* *$ \\
\hline \multirow[t]{5}{*}{ SHORTRATIO } & $t$ & 0.001 & & -0.007 & $* *$ & 0.004 & & -0.005 & \\
\hline & $t+1$ & 0.006 & & -0.001 & & 0.031 & $* * *$ & 0.000 & \\
\hline & $t+2$ & 0.008 & & -0.001 & & 0.027 & $* * *$ & -0.003 & \\
\hline & $t+3$ & 0.006 & & 0.004 & & 0.005 & & 0.003 & \\
\hline & $t+4$ & 0.002 & & 0.009 & $*$ & 0.010 & & 0.008 & \\
\hline \multirow[t]{5}{*}{ RATE } & $t$ & 0.002 & $* * *$ & 0.000 & & 0.001 & & 0.002 & $* * *$ \\
\hline & $t+1$ & 0.003 & $* * *$ & 0.001 & $* *$ & 0.001 & & 0.002 & $* * *$ \\
\hline & $t+2$ & 0.003 & $* * *$ & 0.002 & $* * *$ & 0.002 & & 0.005 & $* * *$ \\
\hline & $t+3$ & 0.005 & $* * *$ & 0.002 & $* * *$ & 0.003 & $* *$ & 0.005 & $* * *$ \\
\hline & $t+4$ & 0.006 & $* * *$ & 0.002 & $* * *$ & 0.003 & $* *$ & 0.004 & $* * *$ \\
\hline
\end{tabular}

Note 1: ***,**,* indicate a significance level of $1 \%, 5 \%$, and $10 \%$, respectively. 
Table 7: Treatment Effect (Effect of Loan Size on Moral Hazard)

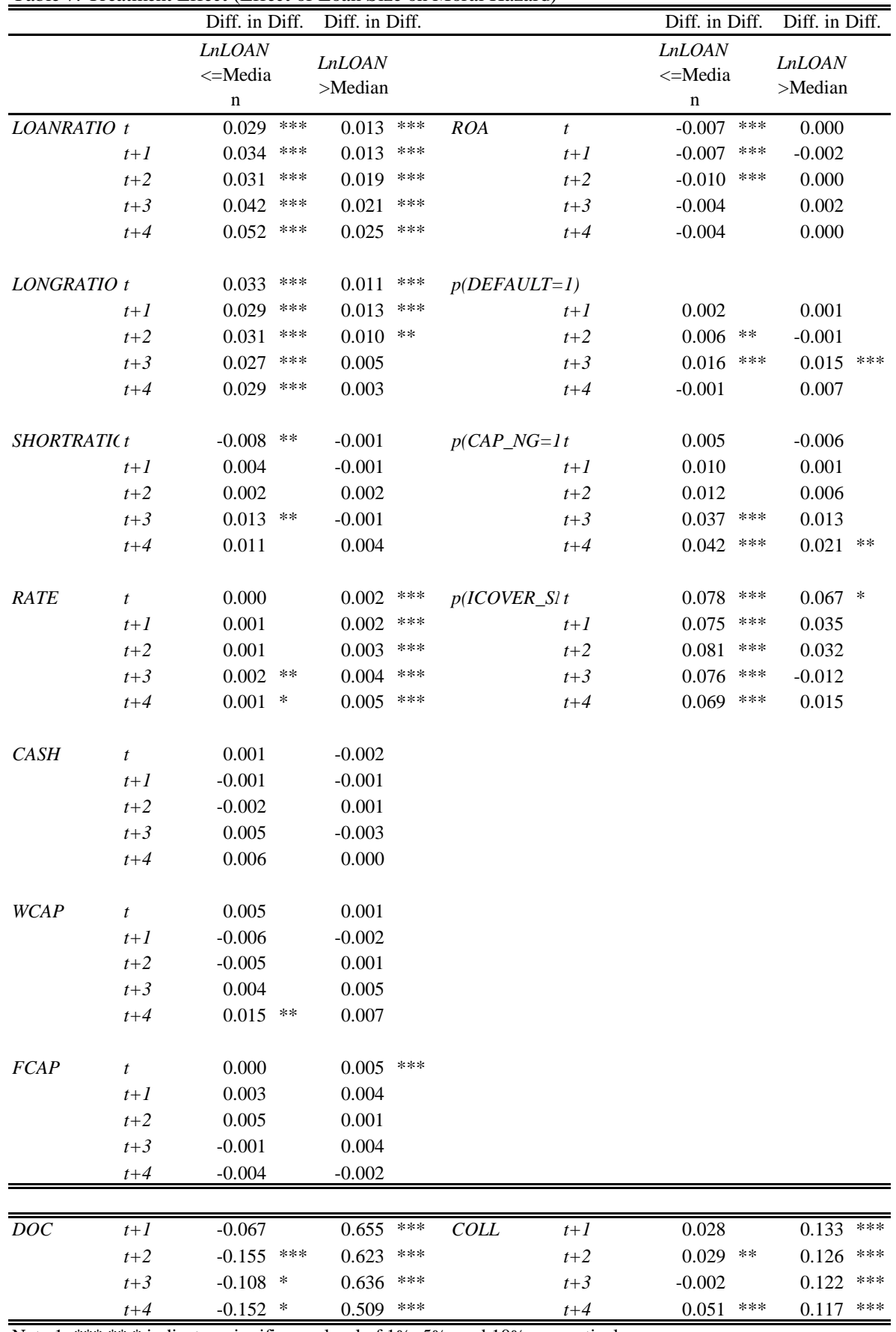

Note 1: $* * *, * *, *$ indicate a significance level of $1 \%, 5 \%$, and $10 \%$, respectively.

Note 2: The treatment effect for each variable is shown in the "Diff. in Diff." column. For example, the treatment effect for LOANRATIO is defined as $\Delta^{2}$ LOANRATIO $_{t+i}=\left(\right.$ LOANRATIO $_{t+i}^{\text {Treatment }}-$ LOANRATIO $\left._{t-1}^{\text {Treatment }}\right)-\left(\right.$ LOANRATIO $_{t+i}^{\text {Control }}-$ LOANRATIO $\left._{t-1}^{\text {Control }}\right)$

The only exception is the variable $p(D E F A U L T=1)$. Since the variable starts from $t+1$ and not from $t-1$, we define its treatment effect as $\Delta p_{t+i}(D E F A U L T=1)=p_{t+i}^{\text {Treatment }}(D E F A U L T=1)-p_{t+i}^{\text {Control }}(D E F A U L T=1)$

Note 3: For each variable, the number of observations differs between $t-1$ and $t+i$ due to the attrition of observations. 
Table 8: Treatment Effect (Effect of Net Worth on Moral Hazard)

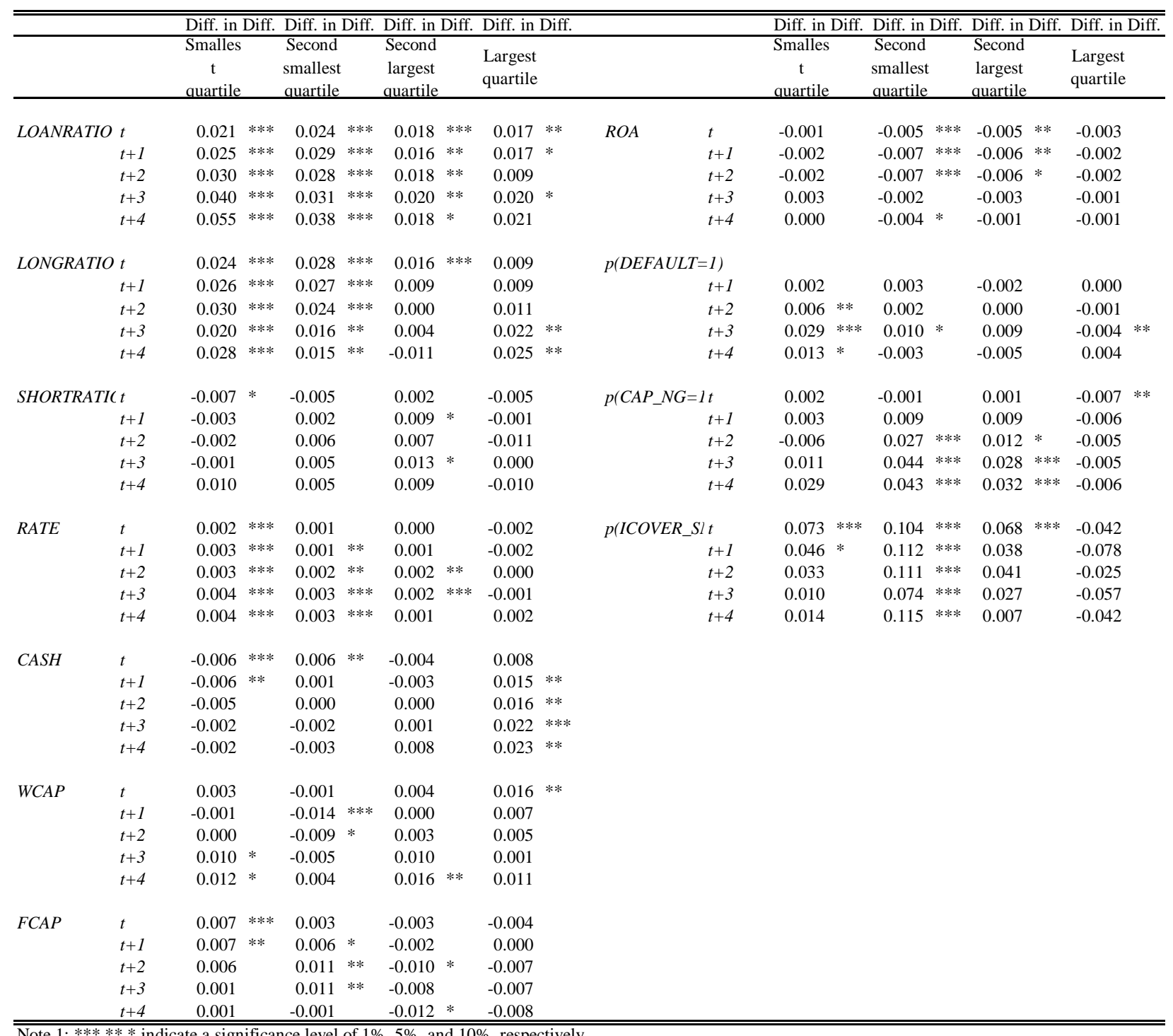

Note $1: * * *, * *, *$ indicate a significance level of $1 \%, 5 \%$, and $10 \%$, respectively.

Note 2: The treatment effect for each variable is shown in the "Diff. in Diff." column. For example, the treatment effect for $L O A N R A T I O$ is defined as

$\Delta^{2}$ LOANRATIO $_{t+i}=\left(\right.$ LOANRATIO $_{t+i}^{\text {Treatment }}-$ LOANRATIO $\left._{t-1}^{\text {Treatment }}\right)-\left(\right.$ LOANRATIO $_{t+i}^{\text {Control }}-$ LOANRATIO $\left._{t-1}^{\text {Control }}\right)$

The only exception is the variable $p(D E F A U L T=1)$. Since the variable starts from $t+1$ and not from $t-1$, we define its treatment effect as

$\Delta p_{t+i}(D E F A U L T=1)=p_{t+i}^{\text {Treatment }}(D E F A U L T=1)-p_{t+i}^{\text {Control }}($ DEFAULT $=1)$

Note 3: For each variable, the number of observations differs between $t-1$ and $t+i$ due to the attrition of observations. 
Figure 1: Guaranteed Loan Amount Outstanding in Japan

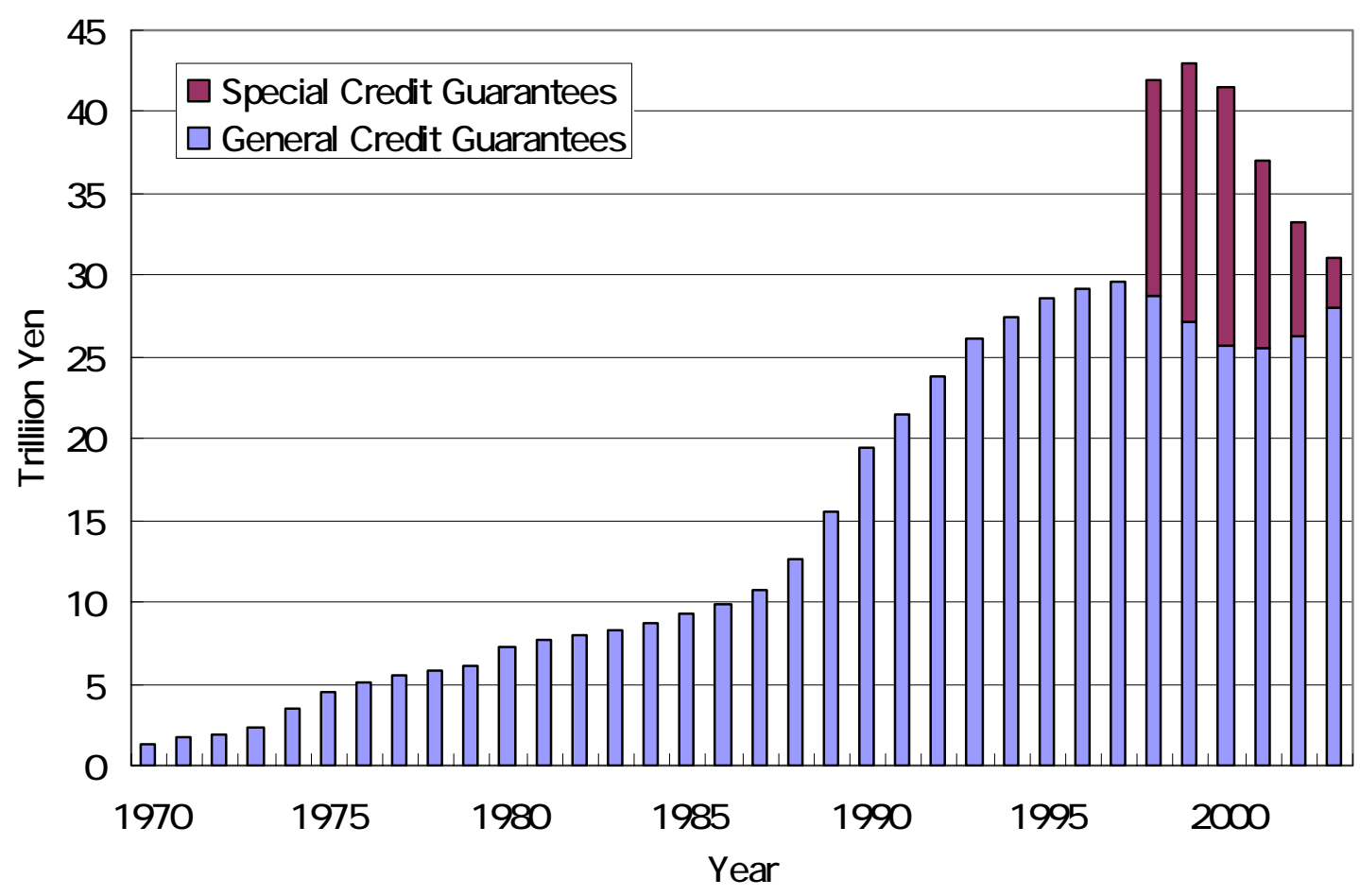

